\title{
Storage Effect on Phenols and on the Antioxidant Activity of Extracts from Anemopsis californica and Inhibition of Elastase Enzyme
}

\author{
Carmen Lizette Del-Toro-Sánchez, ${ }^{1}$ Melesio Gutiérrez-Lomelí, ${ }^{1}$ Eugenia Lugo-Cervantes, ${ }^{2}$ \\ Florentina Zurita, ${ }^{1}$ Miguel Angel Robles-García, ${ }^{1}$ Saul Ruiz-Cruz, ${ }^{3}$ Jose Antonio Aguilar, \\ Juan Alfredo Morales-Del Rio, ${ }^{1}$ and Pedro Javier Guerrero-Medina ${ }^{1}$ \\ ${ }^{1}$ División de Desarrollo Biotecnológico, Centro Universitario de la Ciénega (CUCI), Universidad de Guadalajara (UdeG), \\ Avenida Universidad 1115, Colonia Lindavista, 47820 Ocotlán, JAL, Mexico \\ ${ }^{2}$ Unidad de Tecnología Alimentaria, Centro de Investigación y Asistencia en Tecnología y Diseño del Estado de Jalisco (CIATEJ) AC, \\ Avenida Normalistas 800, Colonia Colinas de la Normal, 44270 Guadalajara, JAL, Mexico \\ ${ }^{3}$ Departamento de Biotecnología y Ciencias Alimentarias, Instituto Tecnológico de Sonora (ITSON), 5 de Febrero 818 Sur, \\ Colonia Centro, 85000 Ciudad Obregón, SON, Mexico \\ ${ }^{4}$ Coordinación de Genómica Alimentaria, Universidad de la Ciénega del Estado de Michoacán de Ocampo (UCM), \\ Avenida Universidad 3000, Colonia Lomas de la Universidad, 59103 Sahuayo, MICH, Mexico
}

Correspondence should be addressed to Carmen Lizette Del-Toro-Sánchez; lizetted@gmail.com

Received 28 March 2015; Accepted 27 April 2015

Academic Editor: Artur M. S. Silva

Copyright (c) 2015 Carmen Lizette Del-Toro-Sánchez et al. This is an open access article distributed under the Creative Commons Attribution License, which permits unrestricted use, distribution, and reproduction in any medium, provided the original work is properly cited.

\begin{abstract}
The amount of total phenols and flavonoids and the antioxidant activity of leaf, stem, and rhizome methanolic extracts from a commonly consumed Anemopsis californica under different storage conditions were investigated. Storage conditions were at 50, 25, 4 , and $-20^{\circ} \mathrm{C}$, protected or not from light, during 180 days. The inhibition of the elastase enzyme was also evaluated. The results demonstrated that leaf, stem, and rhizome methanolic extracts of Anemopsis californica maintain approximately up to 97 and $95 \%$ stability in phenolic content and antioxidant activity, respectively, when stored during 60 days at $-20^{\circ} \mathrm{C}$ in the dark. Additionally, these extracts, principally from leaf and rhizome, showed an elastase inhibitory effect by 75 and $71.8 \%$, respectively. Therefore, this study provides the basis for further research on the anti-inflammatory activity. On the other hand, Anemopsis californica could comprise a good alternative of use as antioxidant in foods.
\end{abstract}

\section{Introduction}

Phenolics are found in all plants as their secondary metabolites and are synthesized during normal development and in response to conditions of stress. These compounds comprise one of the most widely occurring groups of phytochemicals and have many industrial applications in fields such as medicine and cosmetics and in the food industry. To date, less attention has been paid to the stability of polyphenolic compounds and their degradation under different conditions. However, these aspects can substantially influence their potential applications [1].
Polyphenols are divided into several classes, that is, phenolic acids, stilbenes, lignans, and flavonoids [2]. These compounds have received attention for their beneficial biological and pharmacological properties as antioxidants [3]. Among antioxidants, phenolic compounds exhibit a wide range of biological effects, including antibacterial, antiallergic, hepatoprotective, antithrombotic, antiviral, anticarcinogenic, vasodilatory, and anti-inflammatory actions [4].

Inflammation may be defined as a degenerative process that is sufficiently intense to cause local accumulation of lowmolecular-weight (LMW) catabolic products, which in turn elevates osmotic pressure in tissue that, in turn, attracts extra 
fluid [5]. Elastase plays a critical role in inflammation and is the sole enzyme that is capable of degrading elastin. Elastin is the main component of the elastic fibers of the connective tissue and tendons. However, elastase is capable of hydrolyzing nearly all proteins, including the supporting structural proteins of the connective tissues, increasing inflammation $[6,7]$. Therefore, the enzyme has received great attention, primarily because of its reactivity and nonspecificity. An alternative to inhibit elastase is the use of extracts from food plants, because some of them are a good source of antiinflammatory compounds $[6,8,9]$.

Anemopsis californica, commonly known in Spanish as yerba mansa or hierba mansa, is distributed in the southeastern US and in northern and central Mexico [10,11]. The plant has been found in the state of Querétaro (a central state in Mexico) and is employed by local healers to treat a variety of ailments. Fresh- or dry-leaf, rhizome, or root samples are prepared as tinctures, decoctions, and teas for internal use; wilted leaves or root powders are employed externally $[12,13]$. Traditionally, this plant is utilized to prevent and treat venereal diseases [14], rheumatism [15], and cancer [16, 17]. Furthermore, A. californica possesses important antimicrobial [18], antimutagenic [19], and antioxidant [20] activities. Due to its properties, $A$. californica has a great potential in addition to other foods or in pharmaceutical and herbal medicine industries. However, to date and to our knowledge, no antioxidant stability and anti-inflammatory evaluations have been conducted. Therefore, in the present work, the amount of total phenols and flavonoids and the antioxidant activity of leaf, stem, and rhizome methanolic extracts from Anemopsis californica under different storage conditions were investigated. The inhibition of elastase enzyme was also evaluated.

\section{Materials and Methods}

2.1. Reagents. Reagents such as DPPH [2,2-diphenyl-1-picrylhydrazyl], quercetin $\left[3,3^{\prime}, 4^{\prime}, 5,7\right.$-pentahydroxyflavone], ABTS [2,2' -azino-bis(3-ethylbenzothiazoline-6-sulfonic acid)], gallic acid [3,4,5-trihydroxybenzoic acid], Folin-Ciocalteu phenol reagent $2 \mathrm{~N}$, porcine pancreatic elastase (PPE, type IV), and $N$-succ-(Ala)3-p-nitroanilide (ESIV: elastase substrate IV) were purchased from Sigma-Aldrich Co. (USA). All other chemicals and solvents were of the highest commercial grade.

2.2. Methanolic Extraction. Leaves, stems, and rhizomes of Anemopsis californica were collected in Juriquilla, Querétaro (Mexico), in March 2013; they were cut, dried, and ground separately. Three $\mathrm{g}$ of each sample was mixed with $15 \mathrm{~mL}$ of methanol and homogenized in an Ultraturrax (T 25 DS1 digital homogenizer) for $1 \mathrm{~min}$. Afterward, the sample was ultrasonicated (Bransonic, 151-DTH) at $4^{\circ} \mathrm{C}$ for $15 \mathrm{~min}$. The supernatant was collected after centrifugation at 4,000 rpm for $15 \mathrm{~min}$ at $4^{\circ} \mathrm{C}$. The extraction procedure was repeated for a second time. The combined supernatants were evaporated under vacuum conditions at $45-50^{\circ} \mathrm{C}$ (Heidolph Rotavapor, 4003 VAC Senso T) to dryness. The dry extract was weighed to obtain the yield of the extract. After that, it was solubilized in methanol to a final concentration of $14 \mathrm{mg} / \mathrm{mL}$ [19].

2.3. Storage Conditions. Ten $\mathrm{mL}$ of leaf, stem, and rhizome extracts was introduced into glass bottles protected (amber) and not protected (no amber) from light. The samples were stored at $50,25,4$, and $-20^{\circ} \mathrm{C}$ for 180 days. Extract stability was measured every 30 days by determining total phenols, flavonoids, and antioxidant activity (DPPH and ABTS methods). All samples were carried out in triplicate.

2.4. Total Phenols. Determination of total phenolic content was performed by Folin-Ciocalteu method in a 96-well microplate format $[21,22]$. Leaf, stem, and rhizome extracts were diluted in methanol at a ratio of $1: 300,1: 200$, and $1: 100$, respectively. Gallic acid,prepared in six concentrations ranging from 4 to $20 \mathrm{mg} / \mathrm{l}$, was used as standard. Thirty $\mu \mathrm{L}$ of each extract or standard solution, except in a blank probe in which only the solvent was used, was added to $150 \mu \mathrm{L}$ of $0.1 \mathrm{~mol} / \mathrm{l}$ Folin-Ciocalteu reagent and mixed with $120 \mu \mathrm{L}$ of sodium carbonate (7.5\%) after $10 \mathrm{~min}$. Absorbance at $760 \mathrm{~nm}$ was read after $2 \mathrm{~h}$. Phenolic concentration was determined by comparison with the standard calibration curve of gallic acid, and the results are presented as a mean value of tests conducted in triplicate. Total phenol value was expressed as mg of gallic acid equivalents (GAE) per g of dry weight.

2.5. Total Flavonoids. Total flavonoids were determined by utilizing the aluminum chelating method [23]. Fifty $\mu \mathrm{L}$ aliquots of methanol extract were transferred into the test tubes and their volumes were completed up to $750 \mu \mathrm{L}$ with deionized water. After the addition of $250 \mu \mathrm{L}$ of $\mathrm{AlCl}_{3}$ reagent, the tubes were vortexed and maintained at room temperature for $30 \mathrm{~min}$ to allow for the complete reaction between the reagent and the flavonoids. Absorbance of the yellow colored solution was recorded at $405 \mathrm{~nm}$ against blank containing $50 \mu \mathrm{L}$ of methanol. Total flavonoid content was calculated as quercetin equivalents (QE) employing calibration curves prepared with quercetin standard solutions with a concentration range between 10 and $80 \mu \mathrm{g} / \mathrm{mL}$. Total flavonoid value was expressed as mg of QE per g of dry weight.

\subsection{Antioxidant Activity}

2.6.1. DPPH Assay. A free-radical (F-R) DPPH solution was prepared at $6 \times 10^{-5} \mathrm{~mol} / 1[19,24]$. A $0.1 \mathrm{~mL}$ volume of leaf, stem, and rhizome extracts was added to $3.9 \mathrm{~mL}$ of DPPH solution. The decrease in absorbance was determined at $515 \mathrm{~nm}$ at 0 and $30 \mathrm{~min}$ under conditions of darkness. The control sample was prepared containing the same volume without any extract. Methanol was used as the blank. All determinations were carried out in triplicate. The results are reported as \% of inhibition with the following equation:

$\%$ of inhibition

$$
=\frac{(\text { initial absorbance }- \text { final absorbance })}{\text { initial absorbance }} \times 100 \text {. }
$$


TABLE 1: Methanolic extract yields of leaf, stem, and rhizome from Anemopsis californica.

\begin{tabular}{lcccc}
\hline Sample & $\begin{array}{c}\text { Initial dry weight } \\
(\mathrm{g})^{*}\end{array}$ & $\begin{array}{c}\text { Extract weight } \\
(\mathrm{g})^{*}\end{array}$ & $\begin{array}{c}\text { Extract yield } \\
(\mathrm{g} / \mathrm{g} \text { of dry weight })^{*}\end{array}$ & $\begin{array}{c}\text { Extract yield } \\
(\%)^{*}\end{array}$ \\
\hline Leaf & $3 \pm 0.01$ & $0.45 \pm 0.02$ & $0.15 \pm 0.005$ & $15.00 \pm 0.51^{\mathrm{a}}$ \\
Stem & $3 \pm 0.01$ & $0.07 \pm 0.01$ & $0.02 \pm 0.003$ & $2.33 \pm 0.33^{\mathrm{b}}$ \\
Rhizome & $3 \pm 0.01$ & $0.09 \pm 0.01$ & $0.03 \pm 0.003$ & $3.00 \pm 0.38^{\mathrm{c}}$ \\
\hline
\end{tabular}

${ }^{*}$ Mean \pm standard deviation (SD) of three independent experiments. Different letters in each line indicate significant difference at $p<0.05$.

TABLE 2: Changes in total phenols during storage of extracts from Anemopsis californica.

\begin{tabular}{|c|c|c|c|c|c|c|c|c|}
\hline \multirow{2}{*}{$\begin{array}{l}\text { Part of the } \\
\text { plant }\end{array}$} & \multirow{2}{*}{\multicolumn{2}{|c|}{$\begin{array}{c}\text { Treatment } \\
\left({ }^{\circ} \mathrm{C}\right)\end{array}$}} & \multicolumn{6}{|c|}{ Storage time (days) ${ }^{*}$} \\
\hline & & & 0 & 30 & 60 & 90 & 120 & 180 \\
\hline \multirow{8}{*}{ Leaf } & \multirow{2}{*}{50} & PL & $27.8 \pm 0.9$ & $25.3 \pm 1.2$ & $23.1 \pm 0.4$ & $18.6 \pm 0.8$ & $15.3 \pm 1.0$ & $13.9 \pm 0.2^{\mathrm{b}}$ \\
\hline & & NP & $27.8 \pm 0.9$ & $22.5 \pm 0.3$ & $20.9 \pm 0.2$ & $15.3 \pm 0.1$ & $12.8 \pm 0.9$ & $11.1 \pm 0.1^{\mathrm{a}}$ \\
\hline & \multirow{2}{*}{25} & PL & $27.8 \pm 0.9$ & $26.7 \pm 0.9$ & $25.9 \pm 1.8$ & $22.5 \pm 0.7$ & $19.5 \pm 0.2$ & $17.0 \pm 0.6^{\mathrm{c}}$ \\
\hline & & NP & $27.8 \pm 0.9$ & $25.0 \pm 0.1$ & $23.1 \pm 0.6$ & $19.5 \pm 0.8$ & $17.2 \pm 0.2$ & $14.5 \pm 0.3^{\mathrm{b}}$ \\
\hline & \multirow{2}{*}{4} & PL & $27.8 \pm 0.9$ & $27.2 \pm 0.9$ & $27.1 \pm 0.3$ & $27.3 \pm 0.5$ & $21.1 \pm 0.4$ & $19.7 \pm 1.1^{\mathrm{cd}}$ \\
\hline & & $\mathrm{NP}$ & $27.8 \pm 0.9$ & $26.7 \pm 0.4$ & $25.9 \pm 0.2$ & $21.7 \pm 0.3$ & $20.0 \pm 0.6$ & $17.8 \pm 0.2^{\mathrm{c}}$ \\
\hline & \multirow{2}{*}{-20} & PL & $27.8 \pm 0.9$ & $27.2 \pm 0.1$ & $27.0 \pm 0.1$ & $25.3 \pm 0.3$ & $23.6 \pm 0.7$ & $21.7 \pm 0.4^{\mathrm{d}}$ \\
\hline & & NP & $27.8 \pm 0.9$ & $27.0 \pm 0.6$ & $27.0 \pm 0.3$ & $22.2 \pm 0.1$ & $21.1 \pm 0.2$ & $19.5 \pm 0.7^{\mathrm{cd}}$ \\
\hline \multirow{8}{*}{ Stem } & \multirow{2}{*}{50} & $\mathrm{PL}$ & $79.4 \pm 3.5$ & $67.5 \pm 2.1$ & $61.9 \pm 2.7$ & $56.4 \pm 0.8$ & $49.2 \pm 1.1$ & $41.3 \pm 1.5^{\mathrm{b}}$ \\
\hline & & NP & $79.4 \pm 3.5$ & $64.3 \pm 0.9$ & $59.6 \pm 1.6$ & $52.4 \pm 1.2$ & $41.3 \pm 1.5$ & $34.1 \pm 1.0^{\mathrm{a}}$ \\
\hline & \multirow{2}{*}{25} & PL & $79.4 \pm 3.5$ & $76.2 \pm 3.3$ & $67.5 \pm 0.7$ & $63.5 \pm 1.3$ & $53.2 \pm 1.4$ & $46.8 \pm 1.1^{\mathrm{d}}$ \\
\hline & & NP & $79.4 \pm 3.5$ & $75.4 \pm 1.2$ & $65.9 \pm 1.7$ & $58.8 \pm 0.8$ & $48.4 \pm 0.4$ & $44.5 \pm 1.5^{\mathrm{c}}$ \\
\hline & \multirow{2}{*}{4} & PL & $79.4 \pm 3.5$ & $78.6 \pm 0.3$ & $78.1 \pm 1.2$ & $68.3 \pm 1.6$ & $62.7 \pm 1.1$ & $58.0 \pm 2.1^{\mathrm{e}}$ \\
\hline & & NP & $79.4 \pm 3.5$ & $77.8 \pm 0.7$ & $77.0 \pm 0.9$ & $65.1 \pm 1.2$ & $58.8 \pm 1.3$ & $54.0 \pm 0.3^{\mathrm{e}}$ \\
\hline & \multirow{2}{*}{-20} & PL & $79.4 \pm 3.5$ & $78.6 \pm 2.3$ & $77.8 \pm 1.7$ & $69.9 \pm 0.7$ & $64.3 \pm 0.8$ & $61.1 \pm 1.1^{\mathrm{f}}$ \\
\hline & & NP & $79.4 \pm 3.5$ & $77.8 \pm 1.0$ & $77.0 \pm 0.9$ & $67.5 \pm 1.5$ & $61.9 \pm 1.2$ & $54.8 \pm 0.5^{\mathrm{e}}$ \\
\hline \multirow{8}{*}{ Rhizome } & \multirow{2}{*}{50} & $\mathrm{PL}$ & $92.3 \pm 2.8$ & $80.3 \pm 1.5$ & $71.1 \pm 0.8$ & $63.7 \pm 1.3$ & $56.3 \pm 1.7$ & $50.8 \pm 0.9^{b}$ \\
\hline & & NP & $92.3 \pm 2.8$ & $75.7 \pm 1.9$ & $67.4 \pm 2.0$ & $55.4 \pm 0.8$ & $48.9 \pm 1.1$ & $38.8 \pm 2.2^{\mathrm{a}}$ \\
\hline & \multirow{2}{*}{25} & $\mathrm{PL}$ & $92.3 \pm 2.8$ & $87.7 \pm 1.8$ & $78.5 \pm 1.1$ & $71.1 \pm 0.5$ & $63.7 \pm 1.0$ & $57.2 \pm 2.5^{\mathrm{d}}$ \\
\hline & & NP & $92.3 \pm 2.8$ & $85.8 \pm 1.1$ & $73.8 \pm 0.7$ & $67.4 \pm 1.4$ & $58.1 \pm 0.3$ & $52.6 \pm 1.2^{c}$ \\
\hline & \multirow{2}{*}{4} & PL & $92.3 \pm 2.8$ & $90.5 \pm 1.2$ & $90.0 \pm 1.0$ & $76.6 \pm 2.1$ & $72.9 \pm 1.9$ & $69.2 \pm 2.6^{\mathrm{ef}}$ \\
\hline & & NP & $92.3 \pm 2.8$ & $89.5 \pm 1.0$ & $83.1 \pm 0.6$ & $78.5 \pm 1.2$ & $67.4 \pm 2.3$ & $60.0 \pm 0.7^{\mathrm{e}}$ \\
\hline & \multirow{2}{*}{-20} & PL & $92.3 \pm 2.8$ & $91.4 \pm 0.9$ & $91.0 \pm 1.9$ & $80.3 \pm 1.1$ & $75.7 \pm 0.9$ & $72.9 \pm 1.6^{\mathrm{f}}$ \\
\hline & & $\mathrm{NP}$ & $92.3 \pm 2.8$ & $90.5 \pm 1.2$ & $90.1 \pm 1.1$ & $79.4 \pm 0.8$ & $72.0 \pm 1.9$ & $66.5 \pm 2.6^{\mathrm{ef}}$ \\
\hline
\end{tabular}

Data are reported as mg gallic acid equivalents (GAE)/g of dry weight. PL: protect light using amber bottle; NP: not using amber bottle. ${ }^{*}$ Mean \pm standard deviation (SD) of three independent experiments. Different letters in each line indicate significant difference at $p<0.05$.

2.6.2. ABTS Assay. The preformed radical monocation of ABTS was generated by oxidation of ABTS with potassium persulfate as indicated by $\mathrm{Re}$ et al. [25]. From this cation radical solution, $2.97 \mathrm{~mL}$ was added to $0.03 \mathrm{~mL}$ of each extract (leaf, stem, and rhizome). Absorbance was measured spectrophotometrically after $20 \mathrm{~min}$ at $734 \mathrm{~nm}$. The control sample was prepared containing the same volume without any extract. Methanol was used as the blank. Radical scavenging activity (\%) was calculated by the same formula as the DPPH assay.

2.6.3. Assay for Elastase Activity. The effect of extracts on elastase activity was assayed spectrophotometrically by the method of Lee et al. [6]. Porcine pancreatic elastase (PPE, type IV; Sigma) was measured using [ $N$-succ-(Ala)3- $p$ nitroanilide] as the substrate, and the release of $p$-nitroaniline for $20 \mathrm{~min}$ at $25^{\circ} \mathrm{C}$ was monitored. The amount of $p$ nitroaniline was determined by measuring absorbance at $410 \mathrm{~nm}$. The reaction mixture contained $0.2 \mathrm{M}$ Tris-HCI buffer ( $\mathrm{pH} 8.0), 1 \mu \mathrm{g} / \mathrm{mL}$ elastase $(0.046 \mathrm{U} / \mathrm{mL})$, and $0.8 \mathrm{mM}$ succinyl-Ala-Ala-Pro-p-nitroanilide (ESIV: elastase substrate IV, Sigma) as substrate. Leaf, stem, and rhizome extracts were added to the reaction mixture at different concentrations $(0$, $250,500,750$, and $100 \mu \mathrm{g} / \mathrm{mL}$ ). Each inhibitor was preincubated for $20 \mathrm{~min}$ at $25^{\circ} \mathrm{C}$ and the reaction was started by adding substrate. Blanks contained all of the components except for the enzyme. The reaction rate is the slope of 
TABLE 3: Changes in total flavonoids during storage of extracts from Anemopsis californica.

\begin{tabular}{|c|c|c|c|c|c|c|c|c|}
\hline \multirow{2}{*}{$\begin{array}{l}\text { Part of the } \\
\text { plant }\end{array}$} & \multirow{2}{*}{\multicolumn{2}{|c|}{$\begin{array}{c}\text { Treatment } \\
\left({ }^{\circ} \mathrm{C}\right)\end{array}$}} & \multicolumn{6}{|c|}{ Storage time (days) ${ }^{*}$} \\
\hline & & & 0 & 30 & 60 & 90 & 120 & 180 \\
\hline \multirow{8}{*}{ Leaf } & \multirow{2}{*}{50} & $\mathrm{PL}$ & $15.8 \pm 1.2$ & $12.8 \pm 2.0$ & $10.3 \pm 1.1$ & $08.4 \pm 0.9$ & $08.4 \pm 1.7$ & $06.6 \pm 0.4^{\mathrm{b}}$ \\
\hline & & NP & $15.8 \pm 1.2$ & $12.0 \pm 1.4$ & $10.9 \pm 2.9$ & $07.7 \pm 1.0$ & $06.5 \pm 0.7$ & $05.2 \pm 0.2^{\mathrm{a}}$ \\
\hline & \multirow{2}{*}{25} & PL & $15.8 \pm 1.2$ & $14.5 \pm 0.3$ & $14.4 \pm 0.5$ & $12.2 \pm 0.2$ & $09.6 \pm 0.9$ & $08.2 \pm 0.1^{\mathrm{d}}$ \\
\hline & & NP & $15.8 \pm 1.2$ & $13.3 \pm 0.1$ & $12.5 \pm 0.4$ & $10.3 \pm 0.1$ & $08.7 \pm 0.7$ & $07.4 \pm 0.4^{\mathrm{c}}$ \\
\hline & \multirow{2}{*}{4} & PL & $15.8 \pm 1.2$ & $15.5 \pm 0.8$ & $15.3 \pm 0.6$ & $13.0 \pm 0.2$ & $11.5 \pm 0.2$ & $10.4 \pm 0.7^{\mathrm{e}}$ \\
\hline & & NP & $15.8 \pm 1.2$ & $15.0 \pm 1.9$ & $14.2 \pm 2.1$ & $11.2 \pm 0.1$ & $10.9 \pm 0.9$ & $08.7 \pm 0.2^{\mathrm{d}}$ \\
\hline & \multirow{2}{*}{-20} & PL & $15.8 \pm 1.2$ & $15.5 \pm 1.5$ & $15.3 \pm 1.1$ & $14.1 \pm 0.8$ & $12.3 \pm 0.7$ & $11.4 \pm 0.4^{\mathrm{f}}$ \\
\hline & & NP & $15.8 \pm 1.2$ & $15.2 \pm 0.2$ & $13.9 \pm 0.6$ & $12.2 \pm 0.2$ & $11.1 \pm 0.9$ & $10.7 \pm 0.3^{\mathrm{e}}$ \\
\hline \multirow{8}{*}{ Stem } & \multirow{2}{*}{50} & $\mathrm{PL}$ & $23.7 \pm 3.1$ & $19.5 \pm 2.1$ & $17.3 \pm 1.3$ & $16.4 \pm 1.5$ & $13.3 \pm 0.8$ & $10.7 \pm 0.1^{\mathrm{c}}$ \\
\hline & & NP & $23.7 \pm 3.1$ & $18.3 \pm 0.9$ & $16.6 \pm 1.2$ & $14.5 \pm 1.7$ & $13.0 \pm 0.7$ & $08.8 \pm 0.3^{\mathrm{a}}$ \\
\hline & \multirow{2}{*}{25} & PL & $23.7 \pm 3.1$ & $22.1 \pm 0.4$ & $19.2 \pm 0.7$ & $18.7 \pm 1.9$ & $14.9 \pm 1.2$ & $13.1 \pm 1.1^{\mathrm{d}}$ \\
\hline & & $\mathrm{NP}$ & $23.7 \pm 3.1$ & $21.3 \pm 2.2$ & $18.3 \pm 2.0$ & $16.4 \pm 1.1$ & $13.8 \pm 0.9$ & $09.7 \pm 0.8^{\mathrm{b}}$ \\
\hline & \multirow{2}{*}{4} & PL & $23.7 \pm 3.1$ & $23.2 \pm 1.4$ & $23.2 \pm 1.3$ & $19.7 \pm 1.3$ & $18.0 \pm 1.1$ & $15.2 \pm 1.7^{\mathrm{e}}$ \\
\hline & & NP & $23.7 \pm 3.1$ & $23.0 \pm 1.9$ & $21.1 \pm 2.3$ & $18.5 \pm 2.1$ & $15.7 \pm 0.9$ & $13.8 \pm 1.1^{\mathrm{d}}$ \\
\hline & \multirow{2}{*}{-20} & PL & $23.7 \pm 3.1$ & $23.5 \pm 1.8$ & $23.2 \pm 1.7$ & $20.6 \pm 0.7$ & $18.0 \pm 0.3$ & $16.6 \pm 1.0^{\mathrm{f}}$ \\
\hline & & NP & $23.7 \pm 3.1$ & $23.0 \pm 0.4$ & $23.0 \pm 2.1$ & $19.5 \pm 2.2$ & $16.8 \pm 0.7$ & $15.4 \pm 0.6^{\mathrm{e}}$ \\
\hline \multirow{8}{*}{ Rhizome } & \multirow{2}{*}{50} & $\mathrm{PL}$ & $38.1 \pm 1.9$ & $32.4 \pm 1.8$ & $28.6 \pm 2.9$ & $25.1 \pm 3.0$ & $21.0 \pm 2.4$ & $17.5 \pm 1.0^{b}$ \\
\hline & & $\mathrm{NP}$ & $38.1 \pm 1.9$ & $29.7 \pm 0.9$ & $26.3 \pm 1.2$ & $19.4 \pm 2.1$ & $16.4 \pm 0.9$ & $13.3 \pm 0.7^{\mathrm{a}}$ \\
\hline & \multirow{2}{*}{25} & PL & $38.1 \pm 1.9$ & $36.2 \pm 1.1$ & $31.6 \pm 2.5$ & $29.0 \pm 2.3$ & $24.8 \pm 2.1$ & $20.6 \pm 1.8^{\mathrm{c}}$ \\
\hline & & NP & $38.1 \pm 1.9$ & $35.1 \pm 1.8$ & $30.9 \pm 1.5$ & $27.4 \pm 1.1$ & $23.2 \pm 1.0$ & $17.1 \pm 1.7^{\mathrm{b}}$ \\
\hline & \multirow{2}{*}{4} & PL & $38.1 \pm 1.9$ & $37.3 \pm 2.1$ & $37.0 \pm 2.2$ & $30.9 \pm 3.0$ & $29.3 \pm 2.2$ & $24.4 \pm 2.1^{\mathrm{d}}$ \\
\hline & & $\mathrm{NP}$ & $38.1 \pm 1.9$ & $37.0 \pm 0.8$ & $33.5 \pm 1.4$ & $28.2 \pm 1.6$ & $25.9 \pm 0.6$ & $21.7 \pm 2.2^{c}$ \\
\hline & \multirow{2}{*}{-20} & $\mathrm{PL}$ & $38.1 \pm 1.9$ & $37.7 \pm 1.1$ & $37.3 \pm 1.2$ & $32.4 \pm 0.7$ & $30.1 \pm 0.9$ & $27.8 \pm 1.2^{\mathrm{e}}$ \\
\hline & & NP & $38.1 \pm 1.9$ & $37.7 \pm 1.3$ & $37.0 \pm 2.4$ & $32.0 \pm 1.5$ & $29.3 \pm 3.1$ & $24.4 \pm 2.3^{\mathrm{d}}$ \\
\hline
\end{tabular}

Data are reported as mg of quercetin equivalents (QE)/g of dry weight. PL: protected from light using amber bottle; NP: not using amber bottle. ${ }^{*}$ Mean \pm standard deviation (SD) of three independent experiments. Different letters in each line indicate significant difference at $p<0.05$.

the line recorded and is proportional to elastase activity. A control curve was prepared with elastase in the absence of inhibitor. One unit of elastolytic activity is defined as the amount of enzyme releasing $1 \mathrm{mM}$ of $p$-nitroaniline/min. For $p$-nitroaniline, an $\varepsilon$ of 8,800 at $410 \mathrm{~nm}$ was employed. Percentage of inhibition was calculated as follows:

$$
\% \text { of Inhibition }=\left(1-\frac{B}{A}\right) \times 100
$$

where $A$ is the enzyme activity without inhibitor and $B$ is the activity in the presence of inhibitor. Concentrations of extracts required for half maximal inhibitory concentration $\left(\mathrm{IC}_{50}\right)$ were also obtained.

2.7. Statistical Analysis. Data was analyzed by analysis of variance (ANOVA), and the Fisher least significant difference (LSD) test was utilized to identify differences among the means. Changes and significant differences were considered at $P<0.05$. All assays were performed in triplicate.

\section{Results}

3.1. Yields of Methanolic Extracts. Quantitative results of leaf, stem, and rhizome methanolic extracts from A. californica are summarized in Table 1. Leaf extracts exhibited the highest yield, that is, approximately 5 times more than stem and rhizome extracts. The three samples exhibited significant differences. Therefore, the order was leaf $>$ rhizome $>$ stem extracts.

3.2. Changes in Total Phenols and Flavonoids. Highest amounts of total phenols (Table 2) and flavonoids (Table 3) were identified in extracts from rhizome. During storage, high temperature and exposure to light (not using amber bottles) comprised the main factors for degradation of these compounds from A. californica. They were stable during at least 60 days at $4{ }^{\circ} \mathrm{C}$ and at $-20^{\circ} \mathrm{C}$, maintaining 97 and $98 \%$ stability, respectively, in amber bottles. After this time period, total phenols and flavonoids decreased drastically. Final extract degradations among each of the temperatures were different; however, on comparing the same temperature with leaf, stem, and rhizome extracts, similar behavior was observed. At the end of storage (180 days), the best condition in the three extracts was $-20^{\circ} \mathrm{C}$, with amber bottle, the rhizome extract was the most stable, conserving approximately $79 \%$ of total phenols and $73 \%$ of total flavonoid.

3.3. Antioxidant Activity. High temperature and exposure to light were the main factors that decreased antioxidant activity. 


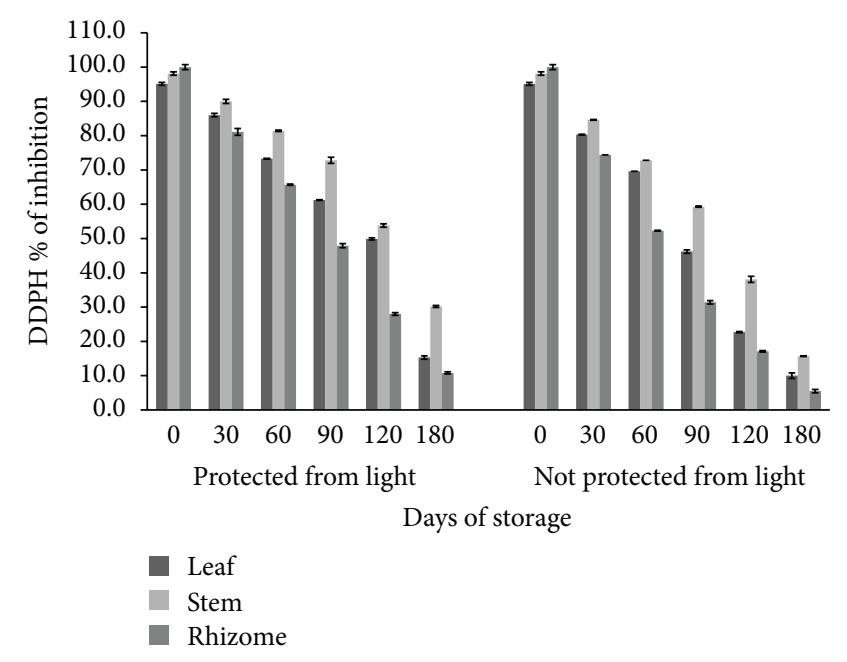

(a)

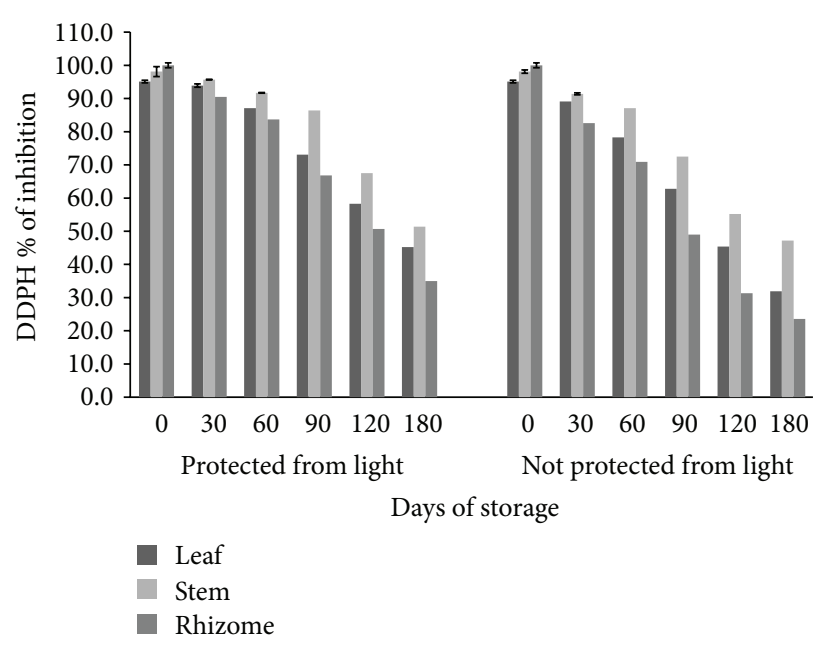

(c)

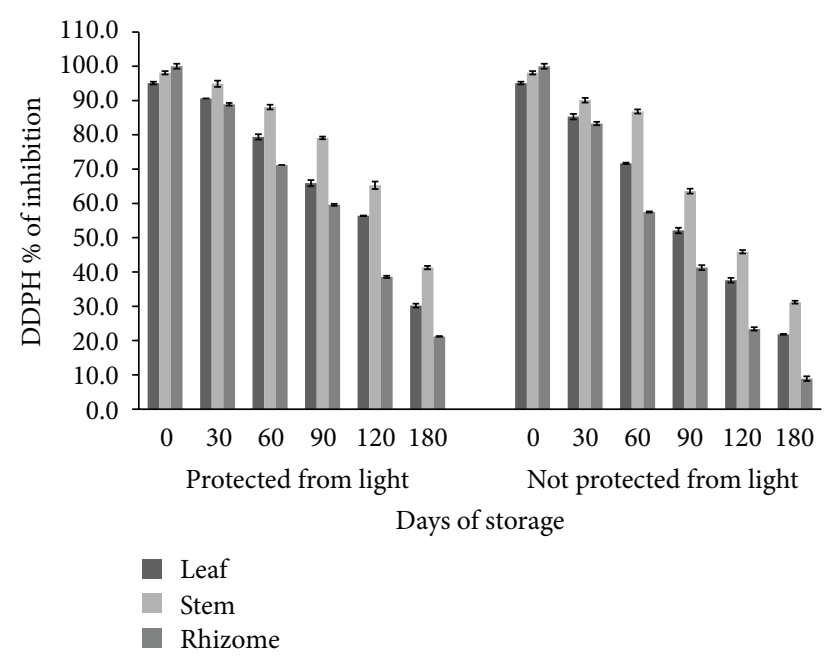

(b)

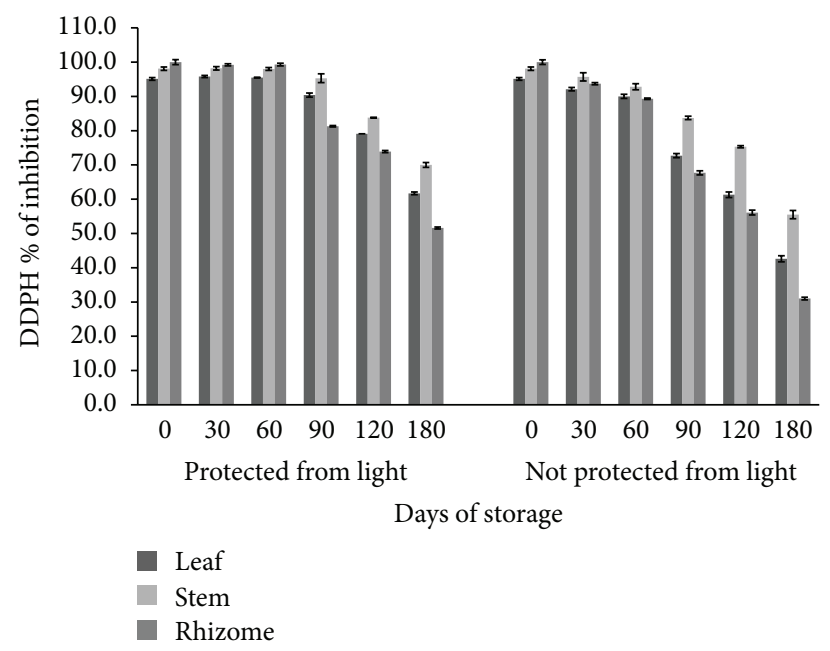

(d)

FIGURE 1: 2,2-Diphenyl-1-picrylhydrazyl (DPPH) \% of inhibition from extracts of Anemopsis californica. Storage during 180 days of storage at $50(\mathrm{a}), 25(\mathrm{~b}), 4(\mathrm{c})$, and $-20^{\circ} \mathrm{C}(\mathrm{d})$, protected and not protected from light.

At the beginning of the experiment using the DPPH method, stem and rhizome extracts presented highest antioxidant activity (Figure 1). However, during storage, the stem extract exhibited best stability in each treatment. A contrasting situation occurred with the rhizome extract with lowest F-R scavenging activity, despite the fact that it possesses the greatest content of phenols and flavonoids. Only at $-20^{\circ} \mathrm{C}$ did all extracts demonstrate up to $95 \%$ stability at 60 days of storage using amber bottles. However, at 180 storage days, the stem extract maintained $70 \%$ of $\mathrm{DPPH}$ inhibition, the highest during this time period (Figure 1(d)). Otherwise, high inhibition of the ABTS radical was observed in the extracts in all of the treatments (Figure 2). The best conditions were found at $4^{\circ} \mathrm{C}(95 \%)$ and $-20^{\circ} \mathrm{C}(98 \%)$ with protection from light from stem extracts (Figures 2(c) and 2(d)). Antioxidant activity using the ABTS radical did not correlate with phenolic content and its behavior was different from that of the DPPH method.
3.4. Elastase Inhibition. Leaf (75\%) and rhizome $(71.8 \%)$ extracts exerted greatest inhibitory effects on PPE activity without a significant difference at the highest concentration (Figure 3). However, there were differences on determination of $\mathrm{IC}_{50}$ values. The rhizome extract required a lower concentration $(361.2 \pm 3.5 \mu \mathrm{g} / \mathrm{mL})$ for $50 \%$ inhibition of the enzyme than the leaf $(492.4 \pm 5.1 \mu \mathrm{g} / \mathrm{mL})$ and stem $(625.5 \pm 4.8 \mu \mathrm{g} / \mathrm{mL})$ extracts.

\section{Discussion}

Differences in the yields obtained in leaf, stem, and rhizome extracts could be caused by several factors, that is, the composition of each particular plant part and differences in solubility and polarity [26]. It is, however, difficult to provide a definite explanation for the results obtained within the scope of the present study. Despite the fact that the leaf extract had the greatest yield, this extract did not present best 


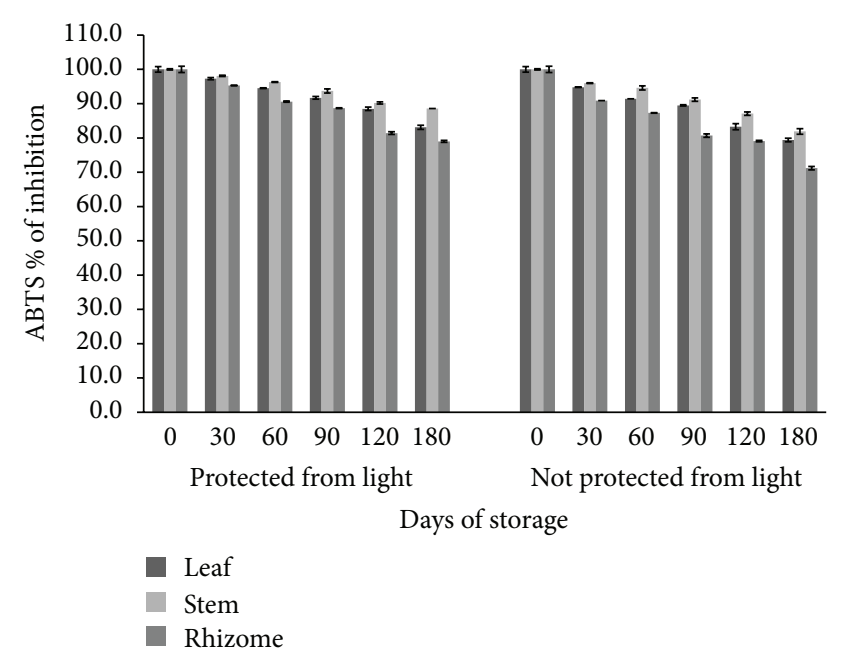

(a)

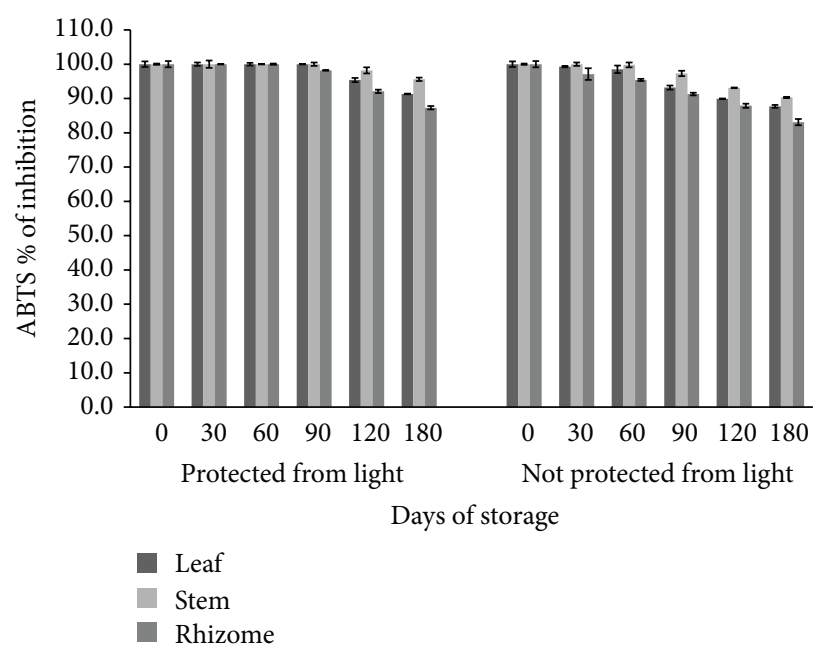

(c)

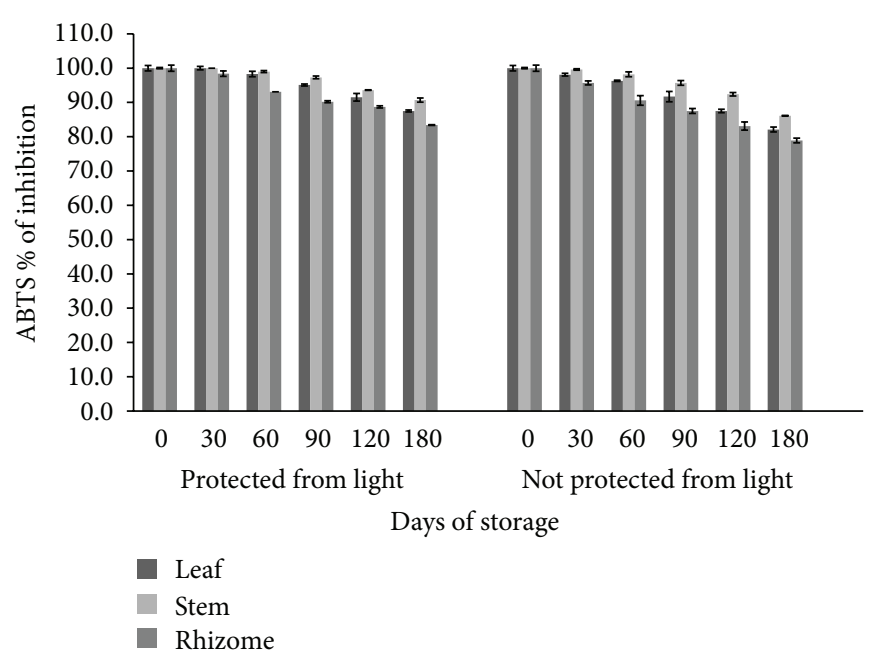

(b)

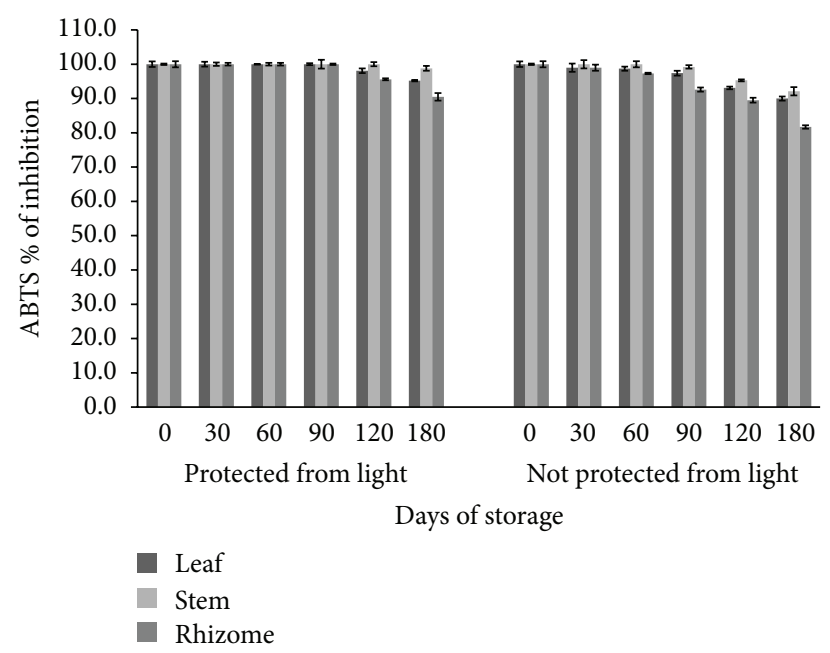

(d)

FIgure 2: 2,2'-Azino-bis(3-ethylbenzothiazoline-6-sulfonic acid) (ABTS) \% of inhibition from extracts of Anemopsis californica. Storage during 180 days of storage at 50 (a), 25 (b), 4 (c), and $-20^{\circ} \mathrm{C}(\mathrm{d})$, protected and not protected from light.

amount of total phenols and flavonoids, nor of antioxidant activity, in comparison with stem and rhizome extracts. However, it inhibited elastase activity at the highest proportion, suggesting the presence of important anti-inflammatory compounds, which could be polyphenols, in the extract [27].

Polyphenol stability under different conditions is a very important aspect that must be taken into account to ensure that phenolic compounds possess the desired properties and maintain their activity under different storage conditions, which can involve high temperatures and light [1]. Within this context, when extracts were exposure to $50^{\circ} \mathrm{C}$ and to light, degradation was faster, presenting a maximum of $60 \%$ degradation at the end of the experiment. The three extracts were very similarly susceptible to polyphenol degradation under these conditions. High temperature and light could change or degrade the structure of the polyphenols, resulting in marked changes in their affinity [28, 29]. However, this effect was not observed at low temperatures, under which they maintained high stability (up of 97\%) during 60 days.
On the other hand, flavonoids are phenolic compounds; hence, the amount of total phenols includes flavonoids, both of which were correlated. Consequently, flavonoids exhibited the same behavior as total phenols.

Radical scavenging activity of leaf, stem, and rhizome methanolic extracts from $A$. californica was evaluated by $\mathrm{DPPH}$ and ABTS assays. In DPPH, the antioxidant activity of the plant extracts could be related with their phenolic content [1]. Contrariwise, in ABTS, the results indicated that antioxidant activity was not correlated with these compounds, suggesting that nonphenolic compounds might engage in major F-R scavenging activity in the plant materials studied [30]. In this latter assay, antioxidant activity was higher than in the DPPH method. At 180 days of storage, the stem extract demonstrated best antioxidant stability in each treatment and radical assay. On the other hand, the rhizome extract was more sensitive to antioxidant degradation. It is probable that antioxidant activity depends not only on phenolic concentration, but also on polarity and the specific 


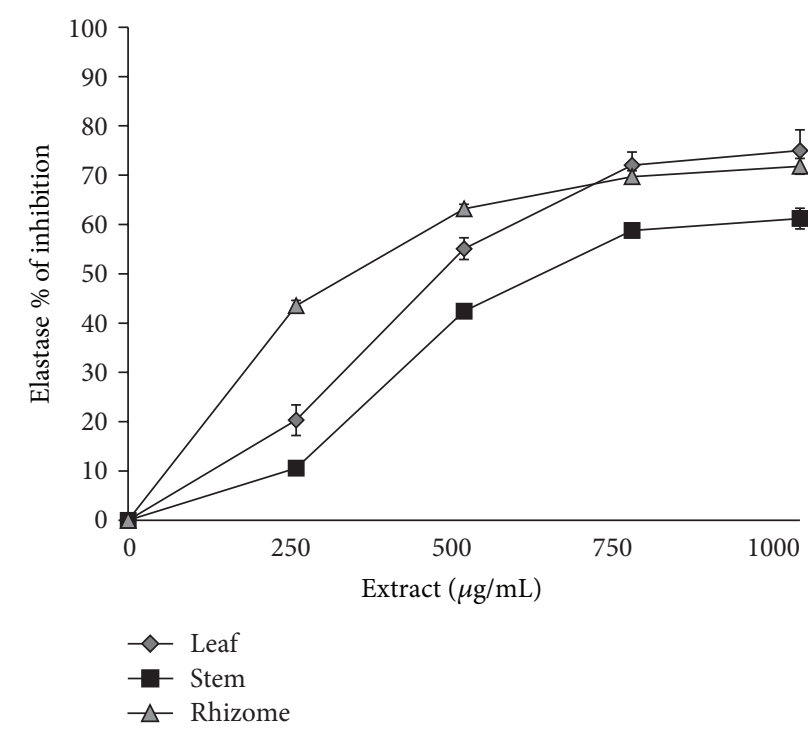

Figure 3: Elastase \% of inhibition from extracts of Anemopsis californica.

chemical structure of each phenolic compound (degree of hydroxylation and extent of conjugation); some works in the literature report examples of hierarchies for phenol antioxidant activity and reduction potential $[28,31]$. This matter could also explain the contrast with high antioxidant activity by means of ABTS assay. Similar results were obtained under similar storage conditions in extracts from sour cherry [2], pomegranate peel [32], cereals [33], mango [34], thuja fruit, and peach [35].

The inhibitory effects of leaf, stem, and rhizome extracts from $A$. californica on elastase activity were investigated. Leaf and rhizome extracts showed highest inhibition. However, inhibition of rhizome was more rapid than that of other extracts; therefore, its $\mathrm{IC}_{50}$ value was lower. This may be due to the different composition of the extracts. Perhaps rhizome extracts contain more compounds related with the enzyme. Within this context, the amount of phenolic compounds was highest in this extract and presented antioxidant activity. These could exert an influence on inhibition of the enzyme, because some investigations demonstrated that antioxidants such as quercetin prevent the elastase activity [27]. On the other hand, our work suggested that the $\mathrm{IC}_{50}$ values of Anemopsis californica extracts are similar to those of antiinflammatory plants, such as Curcuma longa, Alpinia katsumadai, and Areca catechu [6]. However, numerous studies have been conducted in relation to medicinal plants or their active compounds as anti-inflammatory remedies $[6-9,36]$.

In this study, we demonstrated that leaf, stem, and rhizome methanolic extracts from Anemopsis californica maintain high stability in phenolic content and antioxidant activity during 60 days of storage at low temperatures in the dark.

\section{Conclusions}

To our knowledge, there is no previous report on the stability of extracts from Anemopsis californica; thus, this information could provide the basis for further applications in different industries, such as those of the food and pharmaceutical sectors. On the other hand, these extracts, mainly the leaf and rhizome extracts, have an elastase inhibitory effect; nevertheless, more studies are necessaries to deepen on the compounds that act as anti-inflammatory agents through the inhibition of this enzyme. Finally, Anemopsis californica could comprise a good alternative of use as antioxidant in foods.

\section{Conflict of Interests}

The authors declare that there is no conflict of interests regarding the publication of this paper.

\section{Acknowledgment}

This work was supported by a grant from the Mexican Ministry of Education (Secretaría de Educación Pública, SEP) through the Programa de Mejoramiento del Profesorado (PROMEP).

\section{References}

[1] I. Volf, I. Ignat, M. Neamtu, and V. I. Popa, “Thermal stability, antioxidant activity, and photo-oxidation of natural polyphenols," Chemical Papers, vol. 68, no. 1, pp. 121-129, 2014.

[2] M. Kopjar, M. Orsolic, and V. Pilizota, "Anthocyanins, phenols, and antioxidant activity of sour cherry puree extracts and their stability during storage," International Journal of Food Properties, vol. 17, no. 6, pp. 1393-1405, 2014.

[3] P. Cuderman and V. Stibilj, "Stability of Se species in plant extracts rich in phenolic substances," Analytical and Bioanalytical Chemistry, vol. 396, no. 4, pp. 1433-1439, 2010.

[4] E. Middleton Jr., C. Kandaswami, and T. C. Theoharides, "The effects of plant flavonoids on mammalian cells: implications for inflammation, heart disease, and cancer," Pharmacological Reviews, vol. 52, no. 4, pp. 673-751, 2000.

[5] S. V. Stankov, "Definition of inflammation, causes of inflammation and possible anti-inflammatory strategies," The Open Inflammation Journal, vol. 5, no. 1, pp. 1-9, 2012.

[6] K.-K. Lee, J.-H. Kim, J.-J. Cho, and J.-D. Choi, "Inhibitory effects of 150 plant extracts on elastase activity, and their antiinflammatory effects," International Journal of Cosmetic Science, vol. 21, no. 2, pp. 71-82, 1999.

[7] S.-J. Kim, S. A. Sancheti, S. S. Sancheti, B.-H. Um, S.-M. Yu, and S.-Y. Seo, "Effect of 1, 2, 3, 4, 6-penta-O-galloyl- $\beta$-D-glucose on elastase and hyaluronidase activities and its type II collagen expression," Acta Poloniae Pharmaceutica-Drug Research, vol. 67, no. 2, pp. 145-150, 2010.

[8] R. S. Talhouk, C. Karam, S. Fostok, W. El-Jouni, and E. K. Barbour, "Anti-inflammatory bioactivities in plant extracts," Journal of Medicinal Food, vol. 10, no. 1, pp. 1-10, 2007.

[9] N. Maity, N. K. Nema, M. K. Abedy, B. K. Sarkar, and P. K. Mukherjee, "Exploring Tagetes erecta linn flower for the elastase, hyaluronidase and MMP-1 inhibitory activity," Journal of Ethnopharmacology, vol. 137, no. 3, pp. 1300-1305, 2011.

[10] P. A. Munz and D. D. Keck, A California Flora, University of California Press, Oakland, Calif, USA, 1st edition, 1968. 
[11] M. Martínez, Catálogo de nombres vulgares y científicos de plantas mexicanas, Fondo de Cultura Económica, México City, Mexico, 1st edition, 1979.

[12] M. Moore, Medicinal Plants of the Desert and Canyon West, Museum of New Mexico Press, Santa Fe, NM, USA, 1st edition, 1989.

[13] E. Argüelles, R. Fernández, and S. Zamudio, Listado Florístico Preliminar del Estado de Querétaro. Flora del Bajío y de Regiones Adyacentes, Instituto de Ecología Press, Pátzcuaro, México, 1st edition, 1991.

[14] J. D. Adams Jr. and C. Garcia, "Women's health among the Chumash," Evidence-Based Complementary and Alternative Medicine, vol. 3, no. 1, pp. 125-131, 2006.

[15] J. Timbrook, "Virtuous herbs: plants in Chumash medicine," Journal of Ethnobiology, vol. 7, no. 2, pp. 171-180, 1987.

[16] A. L. Daniels, S. van Slambrouck, R. K. Lee et al., "Effects of extracts from two native American plants on proliferation of human breast and colon cancer cell lines in vitro," Oncology Reports, vol. 15, no. 5, pp. 1327-1331, 2006.

[17] C. N. Kaminski, S. L. Ferrey, T. Lowrey, L. Guerra, S. van Severine, and W. F. A. Steelant, "In vitro anticancer activity of Anemopsis californica," Oncology Letters, vol. 1, no. 4, pp. 711715, 2010.

[18] A. L. Medina, M. E. Lucero, F. O. Holguín et al., "Composition and antimicrobial activity of Anemopsis californica leaf oil," Journal of Agricultural and Food Chemistry, vol. 53, no. 22, pp. 8694-8698, 2005.

[19] C. L. Del-Toro-Sánchez, N. Bautista-Bautista, J. L. Blasco-Cabal, M. González-Ávila, M. Gutiérrez-Lomelí, and M. ArriagaAlba, "Antimutagenicity of methanolic extracts from Anemopsis californica in relation to their antioxidant activity," EvidenceBased Complementary and Alternative Medicine, vol. 2014, Article ID 273878, 8 pages, 2014.

[20] T. J. VanderJagt, R. Ghattas, D. J. VanderJagt, M. Crossey, and R. H. Glew, "Comparison of the total antioxidant content of 30 widely used medicinal plants of New Mexico," Life Sciences, vol. 70, no. 9, pp. 1035-1040, 2002.

[21] V. L. Singleton, R. Orthofer, and R. M. Lamuela-Raventós, "Analysis of total phenols and other oxidation substrates and antioxidants by means of folin-ciocalteu reagent," Methods in Enzymology, vol. 299, pp. 152-178, 1998.

[22] L. M. Magalhães, F. Santos, M. A. Segundo, S. Reis, and J. L. F. C. Lima, "Rapid microplate high-throughput methodology for assessment of Folin-Ciocalteu reducing capacity," Talanta, vol. 83, no. 2, pp. 441-447, 2010.

[23] Z. Maksimovic, D. Malencic, and N. Covacevic, "Polyphenol contents and antioxidant activity of Maydis stigma extracts," Bioresource Technology, vol. 96, no. 8, pp. 873-877, 2005.

[24] P. Molyneux, "The use of the stable radical Diphenylpicrylhydrazyl (DPPH) for estimating antioxidant activity," Songklanakarin Journal of Science and Technology, vol. 26, no. 2, pp. 211-219, 2004.

[25] R. Re, N. Pellegrini, A. Proteggente, A. Pannala, M. Yang, and C. Rice-Evans, "Antioxidant activity applying an improved ABTS radical cation decolorization assay," Free Radical Biology and Medicine, vol. 26, no. 9-10, pp. 1231-1237, 1999.

[26] A. Dapkevicius, R. Venskutonis, T. A. Van Beek, and J. P. H. Linssen, "Antioxidant activity of extracts obtained by different isolation procedures from some aromatic herbs grown in Lithuania," Journal of the Science of Food and Agriculture, vol. 77, no. 1, pp. 140-146, 1998.
[27] S. Ganesan, A. N. Faris, A. T. Comstock et al., "Quercetin prevents progression of disease in elastase/LPS-exposed mice by negatively regulating MMP expression," Respiratory Research, vol. 11, article 131, 2010.

[28] A. Baiano, C. Terracone, G. Gambacorta, and E. L. Notte, "Changes in quality indices, phenolic content and antioxidant activity of flavored olive oils during storage," Journal of the American Oil Chemists' Society, vol. 86, no. 11, pp. 1083-1092, 2009.

[29] W. Meng, R. Xiaoliang, G. Xiumei, F. F. Vincieri, and A. R. Bilia, "Stability of active ingredients of Traditional Chinese Medicine (TCM)," Natural Product Communications, vol. 4, no. 2, pp. 1761-1776, 2009.

[30] A. M. Chahardehi, D. Ibrahim, and S. F. Sulaiman, "Antioxidant activity and total phenolic content of some medicinal plants in Urticaceae family," Journal of Applied Biological Sciences, vol. 2, no. 3, pp. 1-5, 2009.

[31] C. A. Rice-Evans, N. J. Miller, and G. Paganga, "Structureantioxidant activity relationships of flavonoids and phenolic acids," Free Radical Biology and Medicine, vol. 20, no. 7, pp. 933956, 1996.

[32] W. Qu, A. P. Breksa III, Z. Pan, H. Ma, and T. H. McHugh, "Storage stability of sterilized liquid extracts from pomegranate peel," Journal of Food Science, vol. 77, no. 7, pp. C765-C772, 2012.

[33] T. Maliar, M. Maliarová, J. Kraic, M. Ondrejovič, I. Pšenáková, and M. Havrlentová, "Thermal and acido-basic stability of antioxidant properties of extracts from cereal and pseudocereal grains," Biologia, vol. 68, no. 1, pp. 99-104, 2013.

[34] P. Maisuthisakul and M. H. Gordon, "Characterization and storage stability of the extract of Thai mango (Mangifera indica Linn. Cultivar Chok-Anan) seed kernels," Journal of Food Science and Technology, vol. 51, no. 8, pp. 1453-1462, 2014.

[35] K. Yogesh and J. Ali, "Antioxidant potential of thuja (Thuja occidentalis) cones and peach (Prunus persia) seeds in raw chicken ground meat during refrigerated $\left(4 \pm 1^{\circ} \mathrm{C}\right)$ storage," Journal of Food Science and Technology, vol. 51, no. 8, pp. 15471553, 2014.

[36] P. C. Braga, M. Dal Sasso, M. Culici, T. Bianchi, L. Bordoni, and L. Marabini, "Anti-inflammatory activity of thymol: inhibitory effect on the release of human neutrophil elastase," Pharmacology, vol. 77, no. 3, pp. 130-136, 2006. 

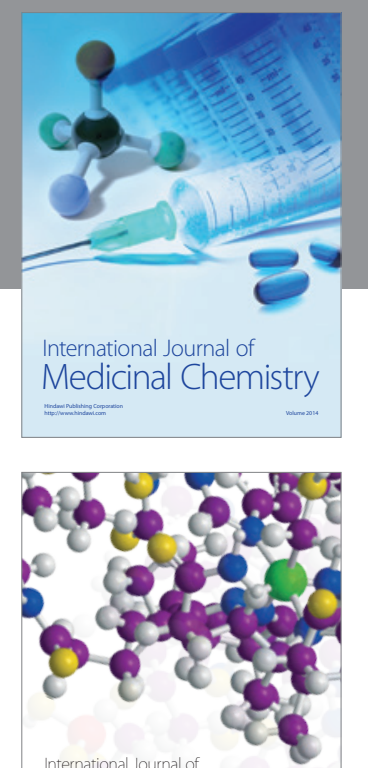

\section{Carbohydrate} Chemistry

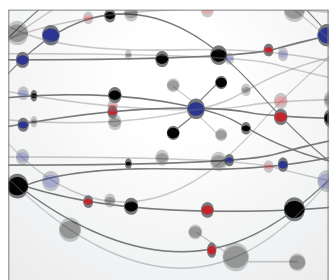

The Scientific World Journal
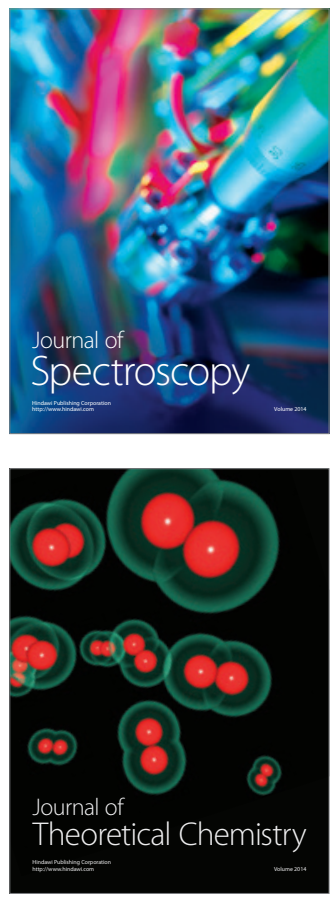
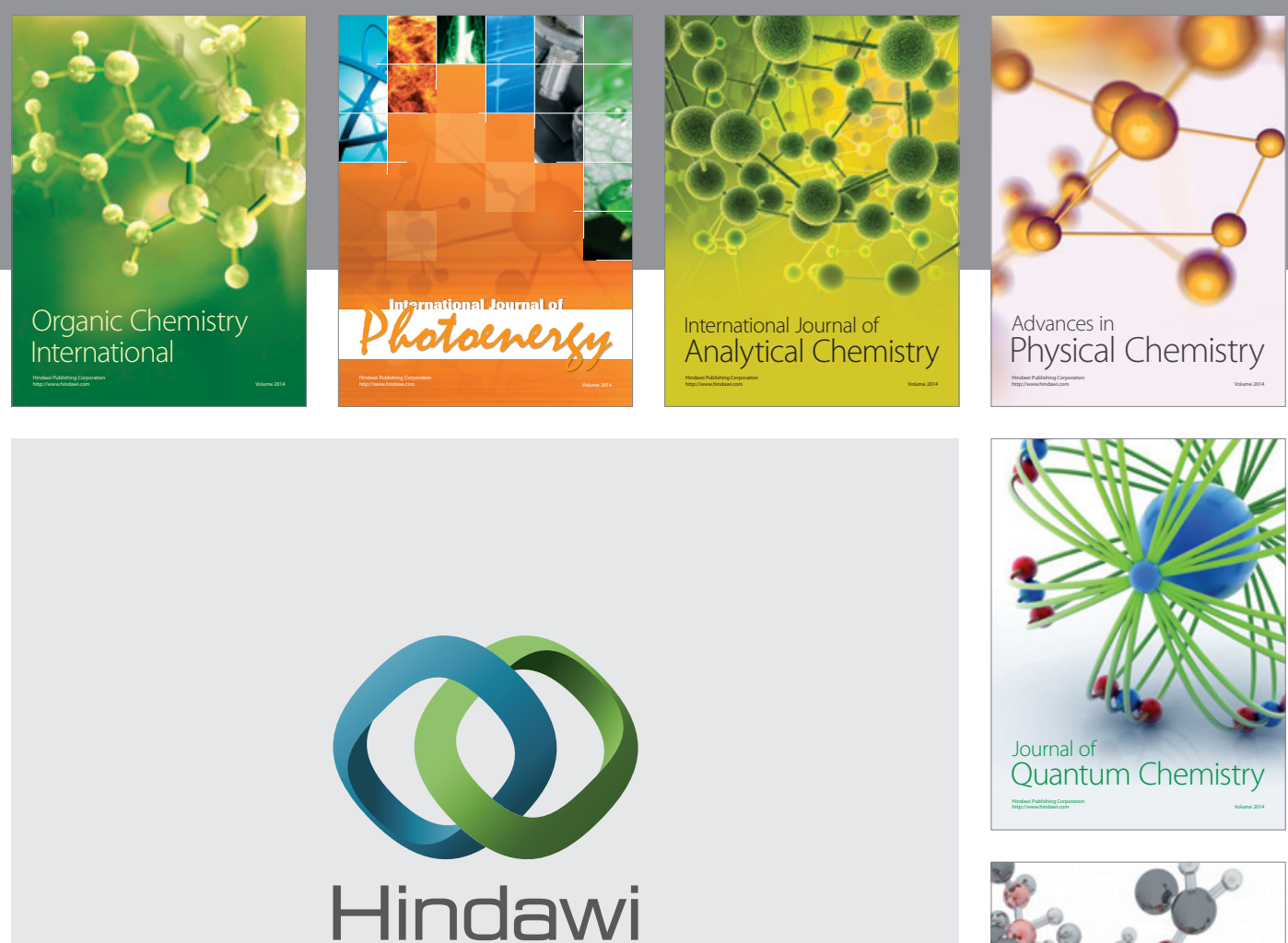

Submit your manuscripts at

http://www.hindawi.com

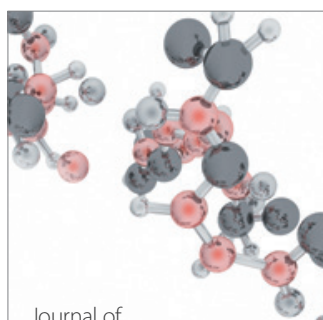

Analytical Methods

in Chemistry

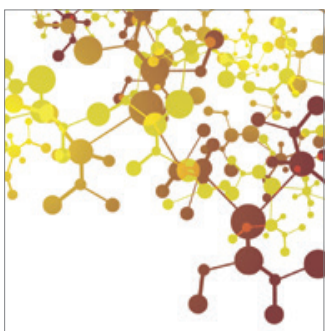

Journal of

Applied Chemistry

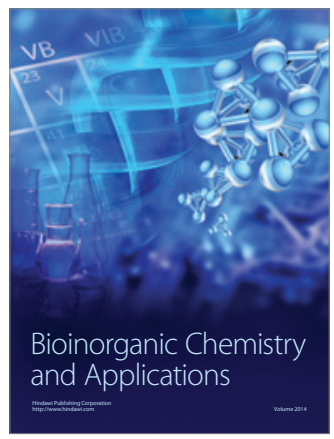

Inorganic Chemistry
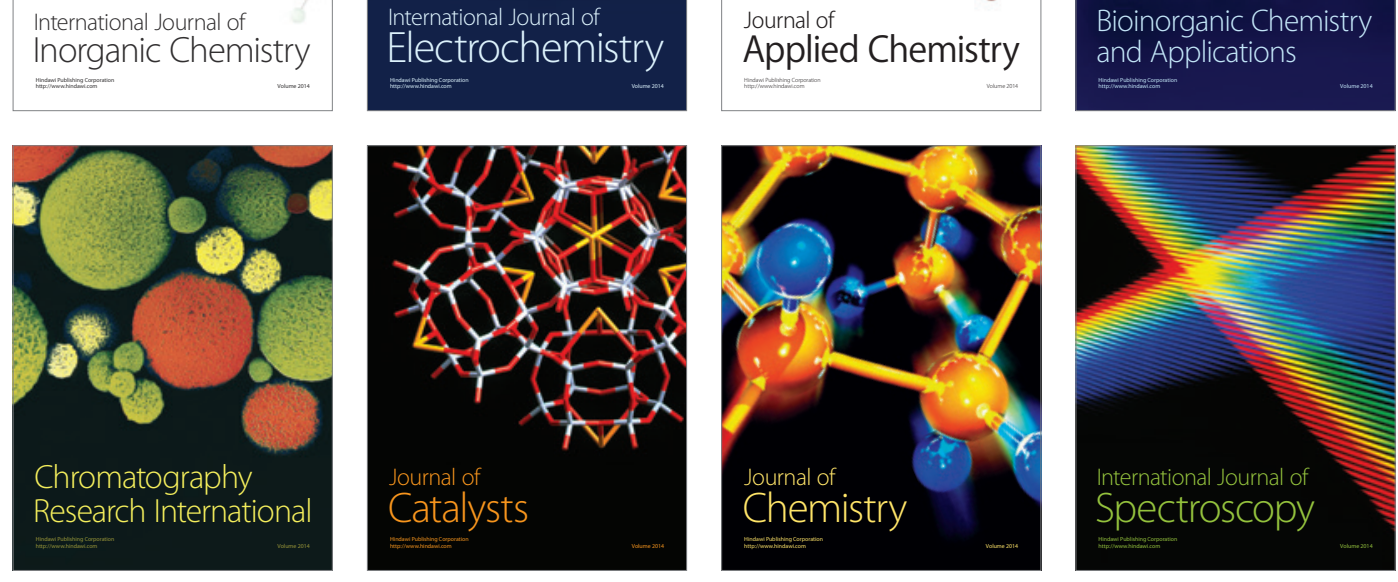